$12 / 5.62980$

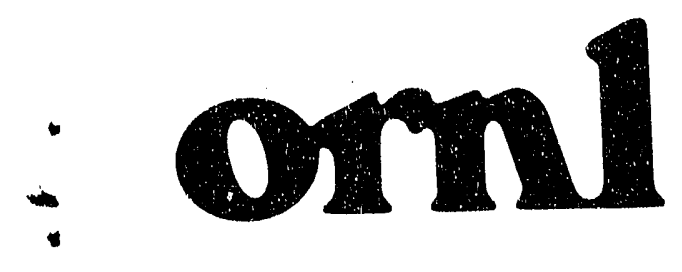

ORNL/TM-12054

miartron malanzera

\title{
Nuclear Medicine Program Progress Report for Quarter Ending December 31,1991
}

\author{
F. F. Knapp, Jr.
}
K. R. Ambrose
A. P. Callahan
A. Hasan
D. W. McPherson
S. Mirzadeh
C. R. Lambert
S. J. Lambert
P. C. Srivastava
D. E. Rice 
This report has been reproduced directly from the best available copy.

Available to DOE and DOE contractors from the Office of Scientific and Technical Information, P.O. Box 62, Oak Ridge, TN 37831; prices avallable from (615) 576-8401, FTS 626-8401.

Available to the public from the National Technical Information Service, U.S. Department of Commerce, 5285 Port Royal Rd., Springfield, VA 22161.

This report was prepared as an account of work sponsored by an agency of the United States Government. Nelther the United States Government nor any agency thereof, nor any of their emplisyees, makes any warranty, express or implied, or assumes any legal liability or responsibility for the accuracy, completeness, or usefulness of any information, apparatus, product, or process disclosed, or represents that its use would not iniringe privately owned rights. Reterence herein to any specific commercial product, process, or service by trade name, trademark, manufacturer, or otherwise, does not necessarily constitute or imply its endorsement, recommendation, or favoring by the United States Government or any agency thereof. The views and opinions of authors expressed herein do not necessarily state or reflect those of the United States Government or any agency thereof. 
Contract No. DE-AC05-84OR21400

Health and Safety Research Division

\section{NUCLEAR MEDICINE PROGRAM PROGRESS REPORT FOR QUARTER ENDING DECEMBER 31, 1991}

F. F. Krapp, Jr., Group Leader
K. R. Ambrose
A. Hasan
A. P. Callahan
C. R. Lambert
D. W. McPherson
S. J. Lambert
S. Mirzadeh
D. E. Rice

P. C. Srivastava

Work sponsored by DOE Office of Health and Environmental Research

Date Published-April, 1992

OAK RIDGE NATIONAL LABORATORY

Oak Ridge, Tennessee 37831-6285

managed by

MARTIN MARIETTA ENERGY SYSTEMS, INC.

for the

U.S. DEPARTMENT OF ENERGY

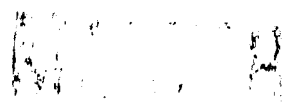


Previous reports in this series:

ORNL/TM-5809

ORNL/TM-11043

ORNL/TM-5936

ORNL/TM-11145

ORNL/TM-6044

ORNL/TM-11224

ORNL/TM-6181

ORNL/TM-11304

ORNL/TM-6371

ORNL/TM-11377

ORNL/TM-6410

ORNL/TM-11427

ORNL/TM-6638

ORNL/TM-11550

ORNL/TM-6639

ORNL/TM-11570

ORNL/TM-6771

ORNL/TM-11721

ORNL/TM-6916

ORNL/TM-11755

ORNL/TM-6958

ORNL/TM-11830

ORNL/TM-7072

ORNL/TM-11881

ORNL/TM-7223

ORNL/TM-11992

ORNL/TM-7411

ORNL/TM-7482

ORNL/TM-7605

ORNL/TM-7685

ORNL/TM-7775

ORNL/TM-7918

ORNL/TM-8123

ORNL/TM-8186

ORNL/TM-8363

ORNL/TM-8428

ORNL/TM-8533

ORNL/TM-8619

ORNL/TM-8746

ORNL/TM-8827

ORNL/TM-8966

ORNL/TM-9037

ORNL/TM-9124

ORNL/TM-9343

ORNL/TM-9394

ORNL/TM-9480

ORNL/TM-9609

ORNL/TM-9707

ORNL/TM-9784

ORNL/TM-9'37

ORNL/TIVi-10082

ORNL/TM-10238

ORNL/TM-10294

ORNL/TM-10377

ORNL/TM-10441

ORNL/TM-10618

ORNL/TM-10711

ORNL/TM-10839

ORNL/TM-11014 


\section{CONTENTS}

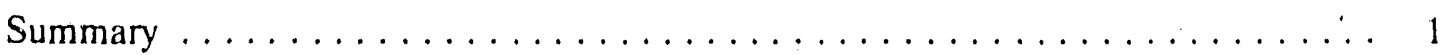

Synthesis of Carrier-Free Rhenium-188-Labeled

$\operatorname{Re}(V)$ DMSA Using Triphenylphosphine as a

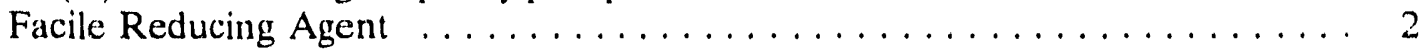

Approaches for Synthesis of 2 -Iodoaltanserine $\ldots \ldots \ldots \ldots \ldots \ldots$

Literature Cited $\ldots \ldots \ldots \ldots \ldots \ldots \ldots \ldots \ldots \ldots \ldots \ldots \ldots \ldots \ldots$

Agents for Medical Cooperatives $\ldots \ldots \ldots \ldots \ldots \ldots \ldots \ldots \ldots \ldots \ldots \ldots$

Other Nuclear Medicine Group Activities $\ldots \ldots \ldots \ldots \ldots \ldots \ldots$ 


\section{SUMMARY}

We have developed a new improved synthesis of carrier-free rhenium-188-labeled $\operatorname{Re}(\mathrm{V})$ dimercaptosuccinic acid (DMSA) complex as a potential therapeutic agent for treatment of thyroid medullary carcinoma. These studies were prompted by the unique localization reported for the analogous technetium-99m-labeled $\mathrm{Tc}(\mathrm{V})$ complex used for diagnosis of this disease. Such therapeutic applications of Re-188 complement our earlier development of an efficient tungsten-188/rhenium-188 generator system. Rather than the use of traditional reducing agents, our new method uses triphenylphosphine (TPP) for the facile reduction of the $\operatorname{Re}(\mathrm{VIII})$ rhenium-188 generator eluant to $\operatorname{Re}(\mathrm{V})$. Rhenium-188 $\operatorname{Re}(\mathrm{V})$ DMSA was then formed in high yield by treatment of the intermediary $\mathrm{Re}(\mathrm{V}) \mathrm{OCl}_{3}(\mathrm{TPP})_{3}$ complex with DMSA.

The in vivo imaging of cerebral serotonin $S_{2}$ receptors by nuclear medicine techniques is of interest for the study of aging and also for the evaluation of Alzheimer disease and dementias. Altanserine binds with high selectivity and specificity to the cerebral serotonin $\mathrm{S}_{2}$ receptors. This project was directed toward the synthesis and evaluation of a series of iodine-125-labeled analogues of altanserine. Our strategy involved preparation of a series of stannylated derivatives of altanserine which would be used for the incorporation of iodine. The first syntheses were therefore directed to the preparation of the necessary bromo derivatives of altanserine. Once these were prepared, we investigated the replacement of the brominated substituent with the trialkylstannyl group and the subsequent iododestannylation reaction to give the desired iodinated analogues. The stannylation of these intermediates under a variety of different reaction conditions, however, did not proceed to give the desired product due to the presence of the sulfur moiety. We then investigated introducing the trialkylstannyl group on other intermediates in the reaction scheme before the introduction of the sulfur moiety. Although we were able to introduce the trialkylstannyl group, the iododestannylation reaction did not proceed due to the deactivation of the phenyl ring by the carbonyl group. This allowed us to explore a number of potential routes, however we have been unable to synthesize the target molecules. One possible route for the synthesis of the iodinated intermediate which we expect will be pursued by collaborators will involve "masking" 
of the carbonyl group as a ketal. This should "activate" the phenyl ring and thus overcome the problem of the iododestannylation reaction encountered above.

Also during this period, several ORNL agents were supplied to Medical Cooperative Programs for further collaborative preclinical and clinical studies.

\section{SYNTHESIS OF CARRIER-FREE RHENIUM-188 LABELED Re(V) DMSA USING TRIPHENYLPHOSPHINE AS A FACILE REDUCING AGENT}

A unique diagnostic application of the technetium- 99 m-labeled $\mathrm{Tc}(\mathrm{V})$ complex of dimercaptosuccinic acid (DMSA) is for the imaging of thyroid medullary carcinoma. For unknown reasons, $\mathrm{Tc}(\mathrm{V})$-DMSA often accumulated in these tumors and other tumors of the head and neck. Since these tumors are often nonresectable, the availability of tumor specific agents radiolabeled with therapeutic radionuclides is of interest. Since rhenium is in the same transition metal group as technetium, the $\operatorname{Re}(V)$ DMSA complex would be expected to be prepared in a similar manner. Our interest in this area developed as a result of our development of a tungsten-188/rhenium-188 generator which provides carrier-frce rhenium-188 (ORNL/TM-10531). Other investigators have demonstrated the preparation of the rhenium(V) and Re-186(V) DMSA complexes by treatment of perrhenate with commercially available kits developed for the preparation of the Tc-(III) DMSA renal perfusion agent. ${ }^{1}$ By increasing the reaction time and temperature, the $\operatorname{Re}(\mathrm{V}) \mathrm{DMSA}$ is formed in an analogous manner as Tc(III)DMSA. ${ }^{2}$

As an alternative route which could be conveniently conducted at room temperature in a short time period, we have explored the use of triphenylphosphine (TPP) as a facile agent for the reduction of perrhenate [e.g., $\operatorname{Re}(\mathrm{VIII})]$ to the requisite $\operatorname{Re}(\mathrm{V})$ oxidation state. These studies have been pursued in conjunction with $\Xi$. C. Lisic, Ph.D., Assistant Professor of Chemistry at the Tennessee Technological University in Cookeville, Tennessee, who is a visiting scientist at ORNL through sujport through the ORAU Participation Agreement Program. 
For this new facile synthesis of $\operatorname{Re}(\mathrm{V}) \mathrm{DMSA}$ (Scheme $\mathrm{I}$ ), perrłenate was reduced with triphenylphosphine (TPP) in an aqueous solution containing $\mathrm{HCl}$, by a modification of the method of Chati et al., ${ }^{3}$ to provide the $\operatorname{ReOCl}_{3}(\mathrm{TPP})_{3}[$ e.g., $\mathrm{Re}(\mathrm{V})]$ intermediate which is extracted into methylene chloride. The $\mathrm{Re}(\mathrm{V}) \mathrm{DMSA}$ is then readily formed by treatment of this intermediate with DMSA in methylene chloride-ethanol (1:1) solution. Following dilution with water, the orange-colored $\operatorname{Re}(V)$ DMSA is then extracted into the aqueous layer. Following evaporation, the product was identified by proton and carbon NMR, infrared spectroscopy, thin layer chromatography, and elemental analysis.

\section{REACTION OF PERRHENATE ION TO FORM A REACTIVE INTERMEDIATE}
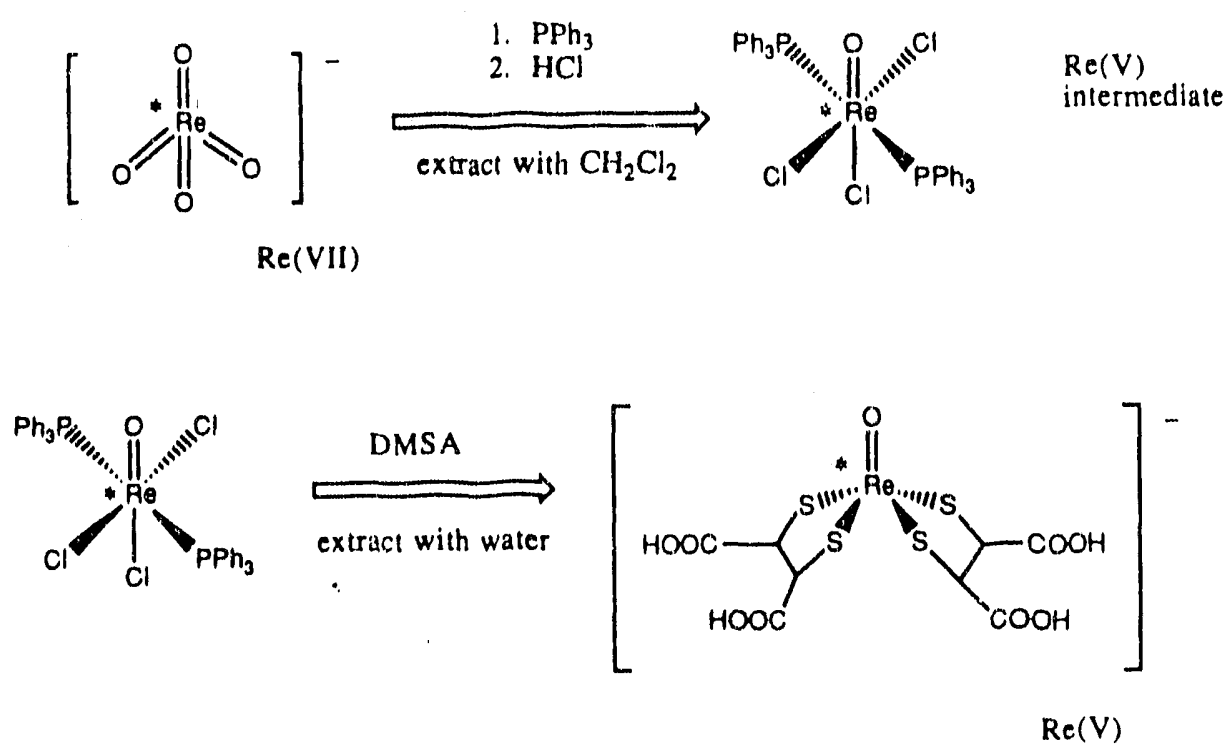

Scheme I

The carrier-free rhenium-188-labeled $\operatorname{Re}(\mathrm{V})$ DMSA was prepared on a scale up to $7 \mathrm{mCi}$ in $>80 \%$ overall yield. In a typical preparation, the physiological saline eluant containing $\mathrm{Na}\left[{ }^{188} \mathrm{Re}\right.$ jperrhenate from the tungsten-188/rhenium-188 generator $(1 \mathrm{ml})$ was treated with a biphasic mixture of methylene chloride and aqueous $\mathrm{HCl}$ containing $1.5 \mathrm{mg}$ of triphenyl phosphine. After shaking for $5 \mathrm{~min}$ at room temperature, the organic layer was separated to yield the $\mathrm{ReOCl}_{3}(\mathrm{TPP})_{3}$ intermediate. Treatment of this solution with $3 \mathrm{mg}$ of 
DMSA in a $10 \%$ ethanol/water solution formed the $\operatorname{Re}(\mathrm{V})$ DMSA complex. The product was conveniently and rapidly purified by passing this solution through an amine SepPak (B). Atter washing with ethanol and $0.01 \mathrm{~N} \mathrm{HCl}$, the product was removed with $5 \mathrm{ml}$ of water.

The product formed by this method shows a single component on TLC analysis with the mobility of an authentic $\operatorname{Re}(\mathrm{V})$ DMSA sample. This simple, high yield method for the preparation of high specific activity $\operatorname{Re}(\mathrm{V})$ DIMSA should allow an evaluation of the usefulness of this agent for the potential treatment of patients with thyroid medullary carcinoma.

\section{APPROACHES FOR SYNTHESIS OF 2'-IODOALTANSERINE .}

Receptors are molecular structures within or on the surface of cells characterized by selective binding of a specific substance or a structural analogue and a specific physiological effect that accompanies the binding. Such receptors in the brain play a central role in neurotransmission for a variety of cerebral processes. The various classes of serotoninergic binding sites, notably the $S_{2}$ receptor site, have been well characterized in pharmacological and physiological terms and have been implicated in several neurological conditions such as aging, Alzheimer's disease, and personality disorders. These observations have generated an increased interest among researchers for the potential non-invasive imaging of the serotonin receptor. The population or activity of receptor binding can be conveniently determined by evaluating the degree of uptake of radiolabeled receptor specific agents. In in vivo studies isch uptake can be evaluated non-invasively using nuclear medicine imaging procedures by injecting radiolabeled receptor agents whose cerebral localization can be determined by measuring the emitted radiation.

This project was directed toward the synthesis and evaluation of a series of iodinated altanserine derivatives for use in the in vivo imaging of serotonin receptor populations by Single Photon Emission Computed Tomography (SPECT). Altanserine (1) is structurally related to ketanserine (2), a ligand which has been radiolabeled and evaluated as a potential candidate for the imaging of serotonin $\mathrm{S}_{2}$ receptor. However, ketanserine has been shown to have a very high non-specific binding to other receptor sites and therefore would produce 
low quality images. In contrast to ketanserine, altanserine contains a thioamide (sultur replaces oxygen) group as a component of the heterocyclic ring system and this change dramatically enhances the $S_{2}$ receptor specificity.<smiles></smiles>

Figure 1.

1) Altanserine $X=S$

2) Ketanserine $X=O$

Ketanserine has been reported to be labeled with iodine-123 in the 2 position via the copper(I) assisted halogen exchange utilizing the brominated precursor in sufficient yield. ${ }^{4}$ When this same procedure was used for the radiolabeling of 1 , the compound undergoes decomposition due to the presence of the sulfur moiety with no radiolabeled product being isolated. In this project we proposed the labeling of altanserine via the trialkylstannyl derivatives as shown in Scheme II.
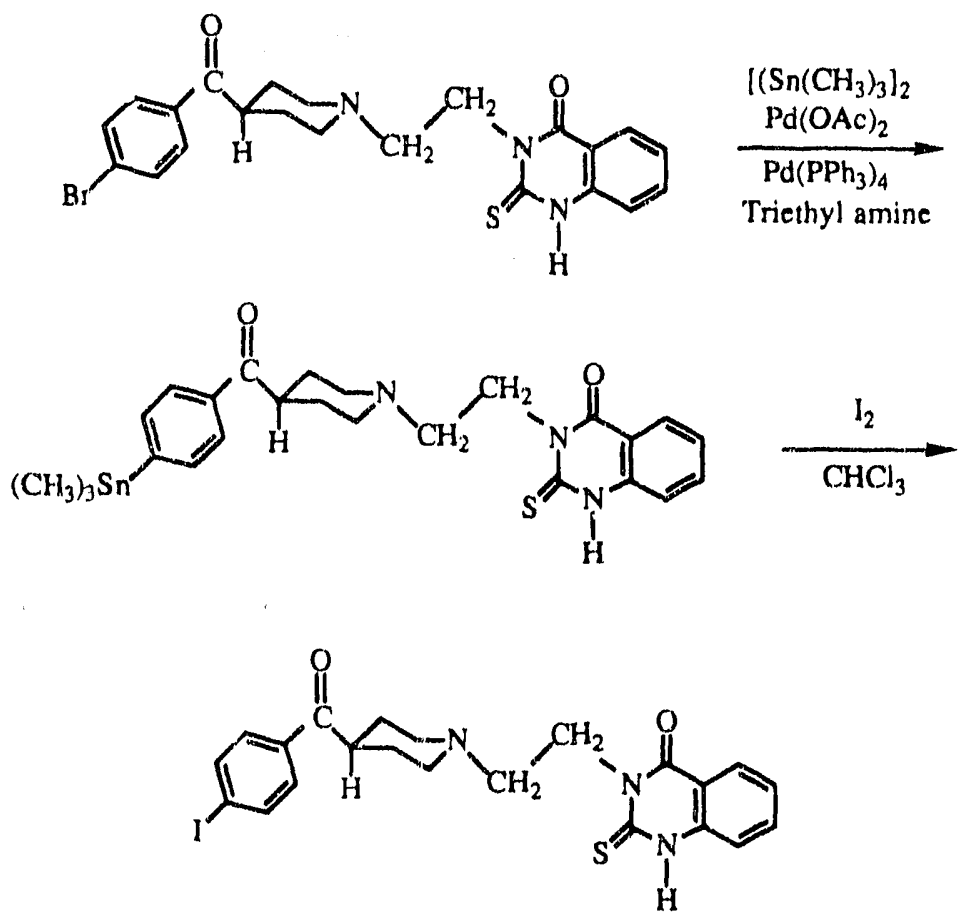

Scheme II. 
This route involves the preparation of a series of brominated derivatives as the target molecules. The derivatives that we initially propesed to synthesize are shown in Figure 2. These are the p-iodo (3) and p-fluoro-(o-iodo (4) analogues. Compound 3 is analogous to that prepared for ketanserine, and compound 4 was chosen from the data observed with similar ligands which showed that placement of the iodine in the position meta to the fluorine atom allows the molecule to retain its affinity for the receptor binding site.

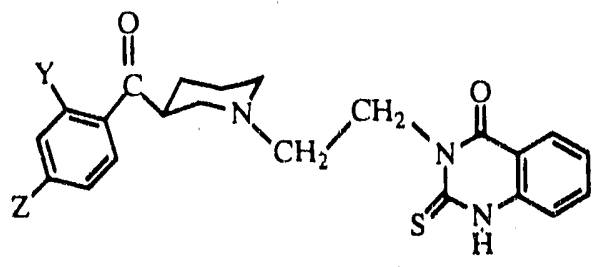

3) $Z=1 \quad Y=H$

4) $Z=F \quad Y=1$

Figure 2.

The initial step for the synthesis of the target molecules involves the preparation of the substituted phenyliperidine ketones. This was accomplished by the route as shown in Scheme III and involves the protection of the amine portion of 4-piperidinecarboxylic acid (5) with acetic anhydride and the subsequent formation of the acid chloride by treatment with thionyl chloride to afford compound 6. The final step involves the Friedel-Crafts acylation of 6 with the substituted benzene derivative in the presence of aluminum chloride. For the p-bromo derivative (7) bromobenzene (11) was used and the desired compound was obtained.

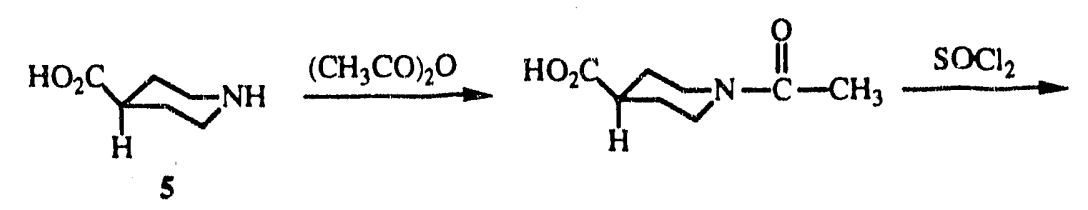<smiles>CC(=O)N1CCC(C(=O)Cl)CC1</smiles>

6

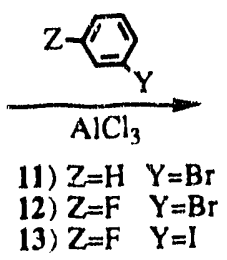

Scheme III.<smiles>[Z]c1ccc(C(=O)C2CCN(C(C)=O)CC2)c([Y])c1</smiles>

7) $\mathrm{Z}=\mathrm{Br} \mathrm{Y}=\mathrm{H}$

8) $Z=F \quad Y=B r$

10) $Z=F \quad Y=H$ 
For the p-fluoro-o-bromo compound (8), 1-fluoro-3-bromobenzene (12) was used and in addition to compound 8 , the p-bromo-o-fluoro isomer (9) was also obtained in the reaction mixture. Compounds $\mathbf{8}$ and $\mathbf{9}$ werc obtained in pure form after repeated column purification and recrystallization. Initially, the reaction was attempted with 1-1luoro-3-iodobenzene (13) to synthesize compound 4 for use as a cold standard and to optimize the subsequent synthetic steps to the target molecules. Under the reaction conditions of the Friedel-Crafts acylation, however, the molecule lost iodine and only the p-tluoro analogue (10) was obtained. Compound 10 was utilized in the subsequent steps to confirm the reaction pathway and to afford a standard sample of altanserine (1) for use as a blocking agent in future animal studies.

The final steps of the reaction sequence employed are shown in Scheme IV using 7 as an example. This involves the removal of the $\mathrm{N}$-acetyl group in $6 \mathrm{M} \mathrm{HCl}$ solution to afford compound 14 followed immediately by the alkylation of 14 with B-chloroethyl-ethylcarbamate to give the desired compound, N-1-(2-ethoxycarbonylaminoethyl)-4-(4-bromobenzoyl)piperidine (15). The ethylcarbamate group was then removed in the presence of $\mathrm{HBr}$ followed by the addition of methyl 2 -isothiocyanatobenzoate to yield the brominated analogue (16) of altanserine. The p-fluoro-o-bromo analogue (17) was prepared in an analogous manner. Compound 16 was then reacted under a variety of conditions with either bistributyltin or hexamethylditin in either anhydrous triethylamine or dioxane as shown in Scheme II. In all cases, however, 16 was recovered from the reaction mixture. In the reactions where triethylamine was used as the solvent, 16 was insoluble and when dioxane was used as the solvent the sulfur moiety of 16 interfered with the palladium catalysts that were used. The replacement of bromine for trialkytin was also attempted on compound 17 and as before the desired product was not isolated.

This lead us to investigate the addition of the trialkyltin group before the sulfur moiety was introduced into the molecule which would presumably eliminate the sulfur interfering with the palladium catalysts employed in the reaction mixture. The reaction of 15 


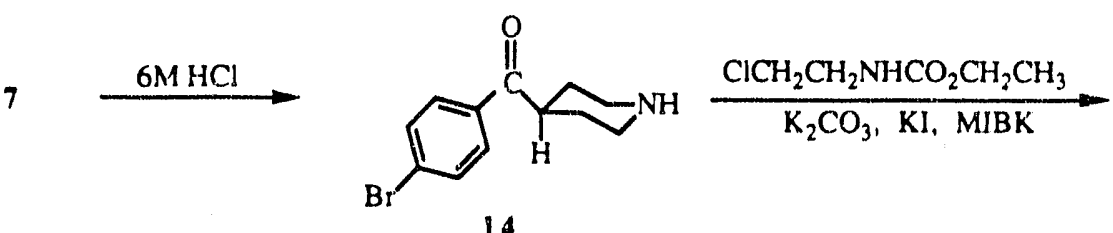<smiles>CCOC(=O)NCC[Al]1CCC(C(=O)c2ccc(Br)cc2)CC1</smiles><smiles>[Z]c1ccc(C(=O)C([2H])CCN2CCN(CC)CC2)c([Y])c1</smiles>

16) $Y=H \quad Z=B r$

17) $\mathrm{Y}=\mathrm{Br} \quad \mathrm{Z}=\mathrm{F}$

\section{Scheme IV.}

with hexamethylditin was carried out as shown in Scheme V. This involved refluxing 15 and hexamethylditin in anhydrous triethylamine in the presence of the palladium catalysts to afford the trimethyltin derivative (18). However, the desired iodinated derivative (3) was not obtained when 18 was reacted with iodine with chloroform as the solvent. The reaction was also performed using the p-fluoro-o-bromo analogue of 15 . Again the iodinated intermediate ivas not isolated, and the crude reaction product was used in the ring closure step. In this case the only product that was formed was altanserine (1) as determined by NMR analysis. The iodination was also carried out with sodium iodide with chloramine- $T$ as the oxidizing agent, and as before, 3 was not formed in the reaction mixture. The iodination at this point did not proceed to give the desired product since the aromatic ring which contains the trimethyltin group is deactivated and this prevents the electrophilic displacement of the trimethyltin group by iodine. 


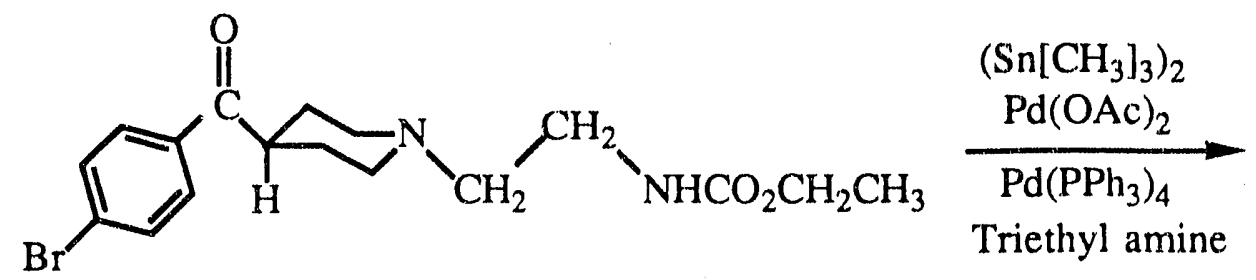

15<smiles>CCC(=O)NCCN1CCC(C(=O)c2ccc(Br)cc2)CC1</smiles>

18

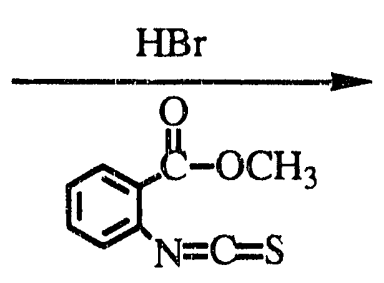<smiles>CCN1CCC(C(=O)c2ccc(I)cc2)CC1</smiles>

3

Scheme V.

The ring closure was also attempted on compound 18 as shown in Scheme V. The $\mathrm{N}$-ethyicarbamate group of 18 was removed by treatment with $\mathrm{HBr}$ followed by ring closure with methyl 2-isothiocyanatobenzoate. In this reaction the unsubstituted analogue of 1 , where the trimethyltin group was displaced by a hydrogen atom, was the only product isolated, and this approach was therefore abandoned.

A phenyl ring containing halogen or the trialkyltin substituent is deactivated due to the presence of the $\alpha$-carbonyl group. This led us to investigate the use of a blocking group which could later be used to mask the deactivating character of the carbonyl group and could 
later be readily removed. We chose the ketal group to block the carbonyl due to its ease of removal in acidic solutions, as showr in Scheme VI for the preparation of compound 3. This reaction scheme is based on the prepas ation of various neuroleptics simiiar to altanserine (1). Compound 7 is reacted with ethylene glycol with p-toluene sulfonic acid as a catalyst to afford the desired ketal (19), which is then reacted with hexamethylditin in the presence of tetrakis(triphenylphosphine)palladium $(0)$ in anhydrous dioxane to give compound 20. When 20 is reacted with iodine, the desired iodinated compound $(21)$ is isolated. Therefore, the masking of the carbonyl group as a ketal does activate the aromatic ring and allows the electrophilic substitution with iodine to proceed. When 21 is treated with $6 \mathrm{M} \mathrm{HCl}$, the ketal and the acetyl groups are both removed. When this intermediate is alkylated with the substituted chloroethylamine, however, the desired product is not isolated. The substituted chloroethylamine compound is recovered from the reaction mixture indicating that the problem with this reaction is the solubility of the chloroethylamine.

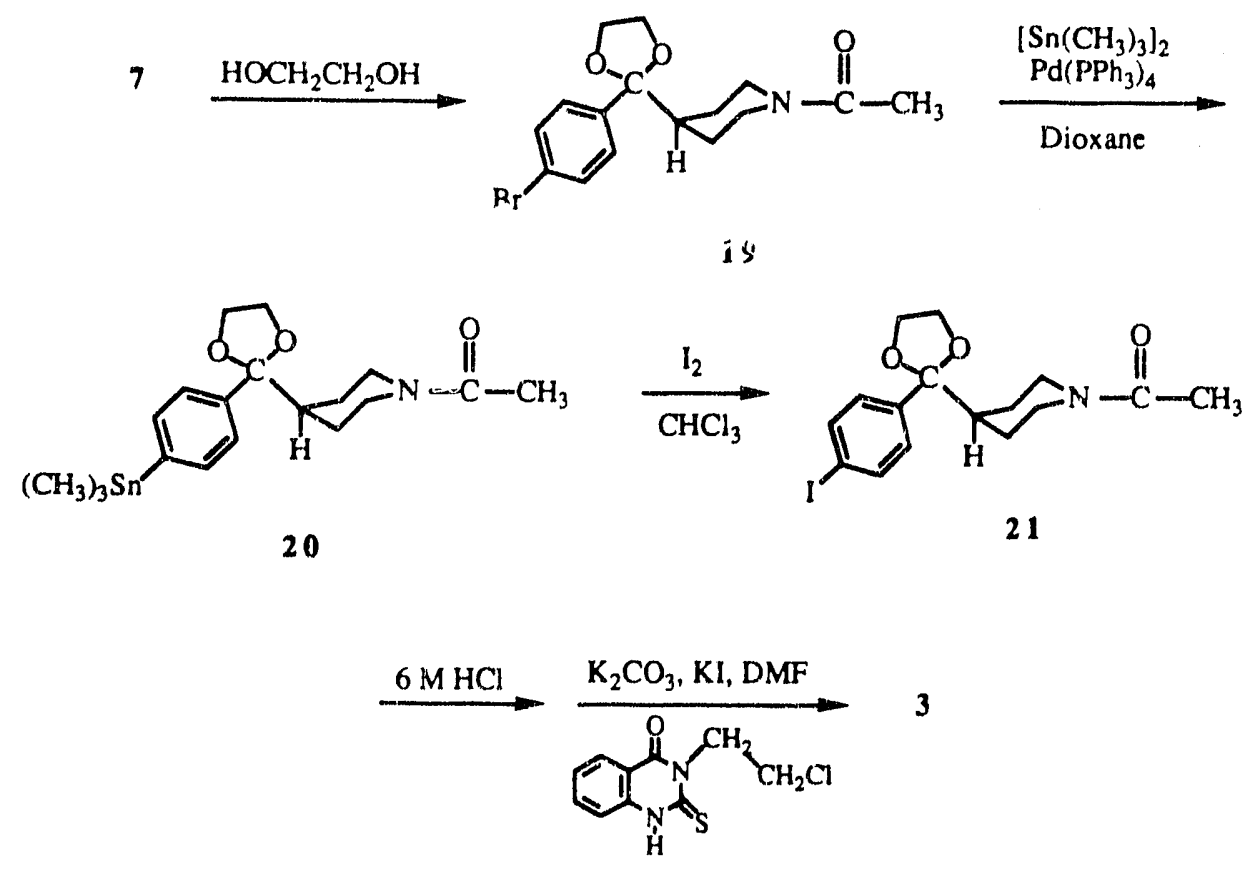

Scheme VI. 
The reaction utilizing compound 15 and performing analogous chemistry as discussed previously is possible since the ketal protecting group can be removed by treatment with $\mathrm{HBr}$, and we have already demonstrated that the ring closure proceeds readily. In addition, this pathway will allow the compound to be radiolabeled in a suitable time frame. If this route is successful for the preparation of the desired analogues of altanserine by cur collaborators in Belgium, we expect to prepare a grant application for the National Institute of Health (NIH). Arrangements have also been made with our collaborators at the University of Liege, Liege, Belgium (Dr. M. Guillaume and colleagues) to test the selectivity and specificity of our new altanserine analogues using animal models with fluorine-18 labeled altanserine, which they routinely produce.

\section{LITERATURE CITED}

1. Clarke, S. E. M., Lazarus, C. R., Wraight, P., Sampson, C., and Maișey, M. N. "Pentavalent [Tc-99m]DMSA, [1-131]MIBG and [Tc-99m]MDP - An Evaluation of Three Imaging Techniques in Patients with Medullary Carcinoma," J. Nucl. Med., 29 , 33-38 (1988).

2. Bisunadan, M. M., Blower, P. J., Clarke, S. E. M., Singh, J., and Went, M. J. "Synthesis and Characterization of [Re-186]Rhenium(V)dimercaptosuccinic Acid: A Possible Tumor Radiotherapy Agent," Appl. Radiat. Isot., 42, 167-171 (1919).

3. Chatt, J., and Rowe, G. A. "Complex ( smpounds of Tertiary Phosphine and a Tertiary Arsine with Rhenium(V), Rhenium(III), and Rhenium(II)," J. Chem. Soc., 4019 (1962).

\section{AGENTS FOR MEDICAL COOPERATIVES}

During this period three shipments each of the tungsten-188/risenium-188 generator were made to Immunomedics, Newark, New Jersey (Dr. Gary Griffiths), Guy's Hospital, 
London, England (Dr. C. Lazarus), and the Nuclear Medicine Institute, Shanghai, P. R. China (Dr. T, Zhu).

\section{OTHER NUCLEAR MEDICINE GROUP ACTIVITIES}

\section{Prescntations}

F. F. Knapp, Jr., presented an invited lecture entitled "Radioisotopes for Radioimmunodetection (RAID) and Radioimmunotherapy (RAIT) - Current and New Perspectives," in the Continuing Education Lectures at the Annual Meeting of the Southeastern Chapter Meeting of the Society of Nuclear Medicine in Hollywood, Florida, on October 11-13, 1991.

Members of the Nuclear Medicine Group co-authored two papers at the "Third International Symposium on Lipid Metabolism in the Normoxic and Ischemic Heart," which was held in Rotterdam, The Netherlands, on September 9-10, 1991.

Sloof, G. W., Visser, F. C., Teerlink, T., Comans, E. F. I., van Eenige, M. J,, van der Vusse, G. J., and Knapp, F. F., Jr. "Phospholipid Distribution of Radioiodinated Fatty Acids After Intravenous Injection in Normoxic Canine Myocardium."

Visser, F. C., Sloof, G. W., van Eenige, M. J., Comans, E. F. I., Teerlink, T., Herscheid, K., and Knapp, F. F., Jr. "Comparison of Uptake, Oxidation, and Lipid Distribution of IHA, IPPA, and DMIPP Fatty Acid Analogues in Normal Canine Myocardium."

\section{Textbook Chapter}

F. F. Knapp, Jr., C. Brihaye (Liege, Belgium), A. P. Callahan, and S. Mirzadeh will author the two sections entitled "Radionuclide Generators for Nuclear Medicine Applications" and "Reactor Production of Medical Radioisotopes," for the second edition of the classic textbook entitled, "Principles of Nuclear Medicine," edited by H. N. Wagner, Jr., M.D. (W. B. Saunders, publishers). The first 896 page edition was published in 1968 and is widely 
recognized as the only comprehensive and authorative text on the principles and practice of nuclear medicine. The second edition is scheduled for publication in 1993, on the 25 th anniversary of the publication of the first edition.

\section{Miscellaneous}

Kathleen R. Ambrose has been appointed as Chairperson of the ORNL Animal Care and Use Committee (ORNL-ACUC). The Committee's responsibilities include review and approval of all procedures and proposals involving the care and use of animals for experimental purposes at ORNL, as well as routine inspections of ORNL animal facilities. Ms. Ambrose attended a workshop entitled "Dilemmas in Rodent Research: Scientific, Regulatory, Ethical Perspectives," in Houston, Texas, December 5-6, 1991.

P. C. Srivastava received a Distinguished Scientist Award given by the United Nations World Development Program and visited research scientists in India to help in India's developmental endeavors in the areas of biomedical and molecular nuclear medicine technologies. Under the World Program, the United Nations will also allow the Council of Scientific and Industrial Research Scientists from India to come to visit the Oak Ridge regional area to interact with scientists for development of new collaborations and technology transfer programs. 
ORNL/TM-12054

\section{INTERNAL DISTRIBUTION}

1. K. R. Ambrose

2. J. F. Allred

3. J. T. Bell

4. T. A. Butler (Consultant)

5. A. P. Callahan

6. E. D. Collins

7. K. F. Eckerman

8. R. K. Genung

9. M. M. Goodman (Consultant)

10. G. D. Griffin

11. A. Hasan

12. J. R. Hightower

13. G. W. Kabalka (Consultant)

14. S. V. Kaye

15-19. F. F. Knapp, Jr.

20. C. R. Lambert

21. S. J. Lambert

22. E. C. Lisic (Consultant)
23. D. W. McPherson

24. J. C. Miller

25. S. Mirzadeh

26. B. Patton

27. G. Prosser

28. D. Pruett

29. D. W. Ramey

30. D. E. Rice

31. D. E. Reichle

32. P. S. Rohwer

33. P. C. Srivastava

34-35. Central Research Library

36. Document Record Section

37-38. Laboratory Records Dept.

39. Lab. Records, ORNL RC

40. ORNL Patent Section

\section{EXTERNAL DISTRIBUTION}

41. H. L. Atkins, M.D., Radiology Dept., State Univ. of New York, Stony Brook, NY 11794.8460

42. H. J. Biersack, M.D., Director, Klinik fuer Nuklear Medizin, Der Universitat Bonn, Sigmund Freud Strasse 25, 5300 Bonn 1, West Germany

43. C. Brihaye, Centre de Recherches du Cyclotron, Universite de Liege, Belgium

44. A. B. Brill, M.D., Ph.D., Dept. of Nuclear Medicine, Univ. of Massachusetts Medical Center, 55 Lake Avenue North, Worcester, MA 01655

45. T. F. Budinger, M.D., zmd 55/121, Lawrence Berkeley Laboratory, 1 Cyclotron Road, Berkeley, CA 94720

46. D. W. Cole, Jr., U.S. DOE, MS-ER-73, GTN, Washington, D.C. 20585

47. J. G. Davis, M.D., Medical and Health Sciences Division, ORAU, Oak Ridge, TN 37831

48. S. J. DeNardo, M.D., Univ. California, Davis Medical Center, Sacramento, CA 95817

49. R. F. Dannals, Division of Nuclear Medicine, Johns Hopkins Medical Institutions, Baltimore, MD 21205-2179

50. R. Dudczak, M.D., Dept. Nuclear Medicine, I. Medizinische Universitatsklinik, A-1090 Wiun, Lazarettgasse 14, Vienna, Austria

51. D. R. Elmaleh, Physics Research Dept., Massachusetts General Hospital, Boston, MA 02114 
52. L. Feinendegen, Institut fur Medizin, Forschingszentrum Julich GimbH, Postfach 1913, D-5170), Julich 1, Germany

53. A. Fritzberg, NeoRx Corporation, 410 West Harrison, Seattle, WA 98119

54. D. M. Goldenberg, M.D., Center of Molecular Medicine and Immunology, 1 Bruce Street, Newark, NJ ()71(1)3

55. M. Guillaume, Chef' de Travaux, Centre de Recherches du Cyclotron, Universite de Liege, Belgium

56. D. R. Hamilton, Director, Division of Technical Development, OTA/CDRH/FDA, 1901 Chapman Avenue, Rockville, MD 20857

57. J. Hiltunen, Technical Research Centre of Finland, Reactor Laboratory, Otakaari 3

A. SF-02150 Espoo, Finland

58. K. Hubner, M.D., Department of Radiology, UT Memorial Hospital, Knoxville, TN 37920

59. A. Jones, HMS Radiology Dept., Shields Warren Radiation Laboratory, 50 Binney Street, Boston, MA 02115

60. G. Kirsch, Department of Chemistry, Universite de Metz, Metz, France

61. J. Kropp, M.D., Klinik fuer Nuklear Medizin, Der Universitat Bonn, Sigmund Freud Strasse 25, 5300 Bonn 1, West Germany

62. D. E. Kuhl, M.D., Division of Nuclear Medicine, University of Michigan Hospitals, University Hospital BIG 412/0028, 1500 E. Medical Center Drive, Ann Arbor, MI 48109-(0028.

63. S. Larson, M.D., Sloan-Kettering Inst. for Cancer Research, New York, NY.10021

64. D. J. Maddalena, FRACI, Department of Pharmacology, Sydney University, NSW 2006, Sydney, Australia

65. Office of Assistant Manager for Energy Research and Development DOE-ORO, Oak. Ridge, TN 37831

66. R. Patterson, M.D., Nuclear Cardiology, Crawford Long Hospital, 550 Peachtree Street, NE, Atlanta, GA 30365-2225

67. C. L. Partain, M.D., Professor and Vice Chairman, Dept. Radiology and Radiological Sciences, Vanderbilt University Medical Center, Nashville, TN 37232

68. R. C. Reba, M.D., 5841 S. Maryland Ave., U.C. Hospital Box 429, Chicago, IL $6(1637$

69. M. Robbins, Mallinckrodt, Inc., 675 McDonnell Blvd., P.O. Box 5840, St. Louis, MO 63134

70. M. P. Sandler, M.D., Chief, Nuclear Medicine Section, Vanderbilt University Medical Center, Nashville, TN 37232

71. R. L. Schenter, HO-37, Westington Hanford Co., P.O. Box 1970, Richland, WA 99352

72. F. Snyder, ORAU, Oak Ridge, TN 37831

73. A. Solomon, M.D., UT MRCH, 1924 Alcoa Highway, Knoxvilie, TN 37920-6999

74. P. Som, DVM, Medical Department, BNL, Upton, NY 11973

75. S. C. Srivastava, Bldg. 801, Medical Dept., BNL, Upton, NY 11973

76. H. W. Strauss, M.D., Nuclear Medicine Div., Massachusetts General Hospital, Boston, MA 02114

77-87. Office of Scientitic and Technical Information, DOE, Oak Ridge, TN 37831

88. F. Visser, M.D., Cardiology Dept., Free University Hospital, De Boelelaan 11\%, Amsterdam, The Netherlands

89. H. N. Wagner, Jr., M.D., Div. of Nuclear Medicine, Johns Hopkins Medical Institutions, $615 \mathrm{~N}$. Wolfe Street, Baltimore, MD 21205-2179

90. A. P. Wolf, BNL, Upton, NY 11973 
91. R. Wolfangel, Mallinckrodt, Inc., 675 McDonnell Blvd., P.O. Box 5840, St. Louis, MO 63134

92. D. V. Woo, Centocor, 244 Great Valley Parkway, Malvern, PA 19355

93. R. W. Wood, Jr., DOE-OHER, Washington, DC 20585

94. S. Wynchank, Research Institute for Medical Biophysics (RIMB), Republic of South Africa 

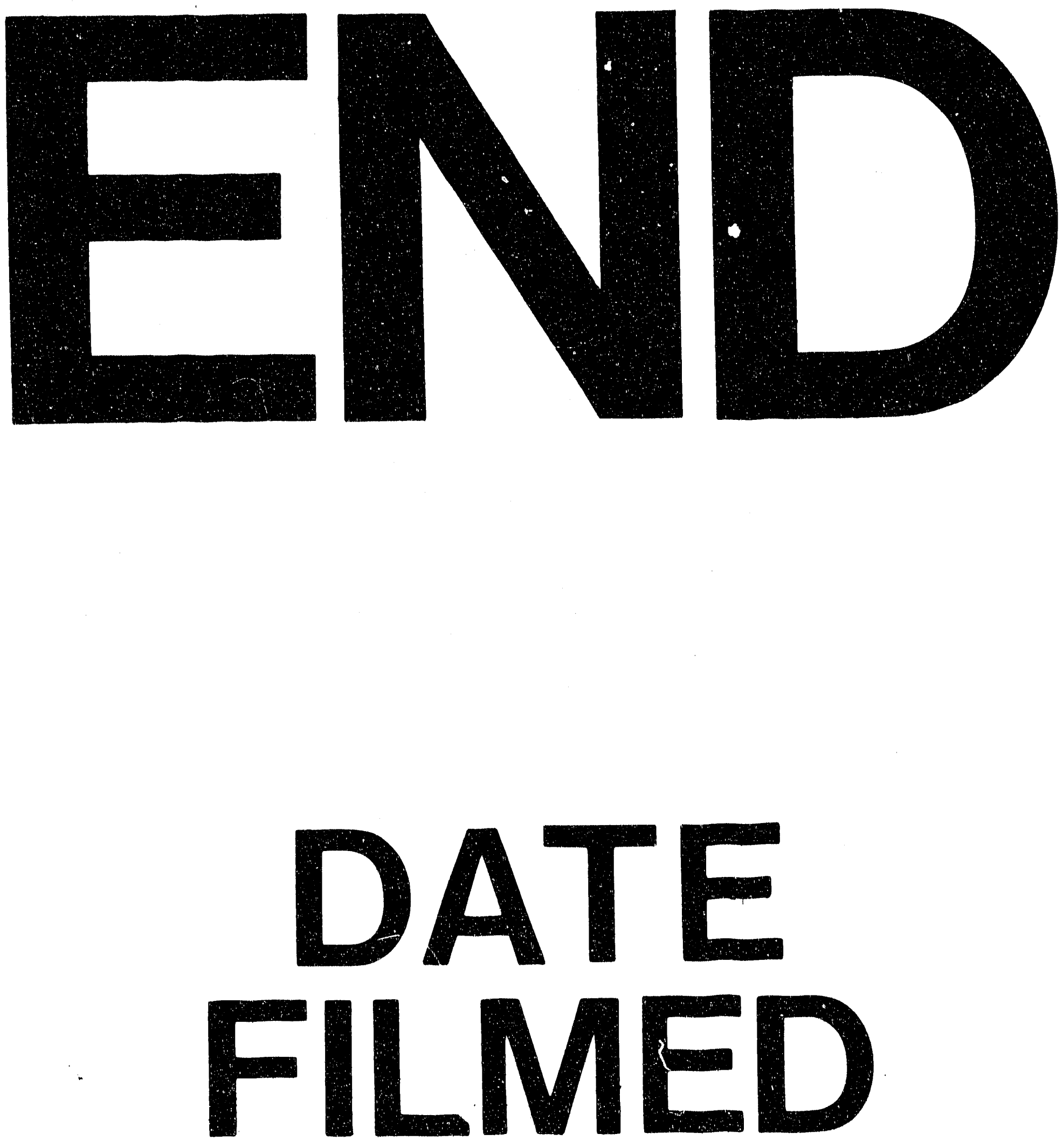

1

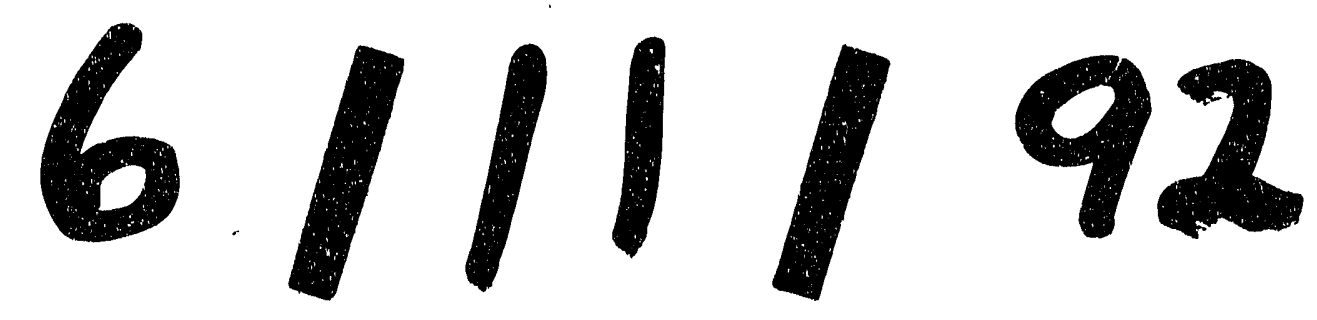


